Litrlewood, D. \& Postgate, J. R. (1957). J. gen. Microbiol. 17, 378-389

\title{
Sodium Chloride and the Growth of Desulphovibrio desulphuricans
}

\author{
By DOROTHY LITTLEWOOD AND J. R. POSTGATE
}

Chemical Research Laboratory, Teddington, Middlesex

\begin{abstract}
SUMMARY: The effect of sodium chloride on the multiplication of four freshwater and three salt-water strains of sulphate-reducing bacteria was examined by determining the numbers of organisms in a known population which were viable in media of unfamiliar $\mathrm{NaCl}$ concentrations. The salt-water strains all produced variants viable at high $\mathrm{NaCl}$ concentrations; a population able to multiply in $1 \%$ $10 \% \mathrm{NaCl}$ was obtained by 'training' one salt-water strain. They differed, however, in the frequency with which non-exacting variants appeared, ranging from a strain in which the whole population grew with $0.25 \% \mathrm{NaCl}$ to one which would not grow with less than $0.45 \% \mathrm{NaCl}$ even after repeated attempts at acclimatization. Replacement experiments indicated that the exigent strain required chloride ion; a lessexacting strain required sodium ion. The fresh-water strains produced few variants viable at $\mathrm{NaCl}$ concentrations above $3 \%$, but one strain produced variants of the salt-water type after 'training' to grow with $4 \% \mathrm{NaCl}$; sodium ion was mainly responsible for the inhibition of this strain by high $\mathrm{NaCl}$ concentrations. We conclude that the differences among the salt- and fresh-water strains of Desulphovibrio do not at present justify their separation into the two species aestaurii and desulphuricans.
\end{abstract}

The sulphate-reducing bacteria are common inhabitants of marine, estuarine and fresh-water environments, and laboratory strains frequently show wide differences in tolerance of $\mathrm{NaCl}$. Whether these differences are sufficient to justify a separate classification of marine and fresh-water types has been disputed. Van Delden (1903) tentatively distinguished between Microspira (now Desulphovibrio) desulphuricans, the fresh-water species, and Microspira aestuarii, the salt-water species, on the grounds that neither would multiply in a medium containing the salt concentration appropriate to the other. Gahl \& Anderson (1928) found that the majority of strains obtained from oil-well water grew with $0-3 \% \mathrm{NaCl}$, but that minorities of exacting or salt-sensitive types existed. They inclined to the view that the exigent and sensitive strains were variants of desulphuricans, the prevalent species. Baars (1930) and Kluyver \& Baars (1932) did not favour a separate species aestuarii, having shown that fresh-water strains could be 'trained' to multiply in a medium containing $3 \% \mathrm{NaCl}$, and that marine strains could undergo the reverse change; but Rittenberg (1941) was unable to repeat the latter observation with two marine strains. Miller (1949) showed that fresh-water strains were readily trained to grow in media containing $4 \% \mathrm{NaCl}$, and grew more rapidly after one passage in such a medium. As a result of tests with many strains originating from sulphur domes he recommended $1 \% \mathrm{NaCl}$ as the salt concentration permitting fastest growth and most sulphide formation. Baars (1930) noted that $\mathrm{NaCl}$ at $0 \cdot 6-0.9 \%$ stimulated sulphide production by fresh-water strains, 
a phenomenon which he believed partly accounted for an increased $\mathrm{H}_{2} \mathrm{~S}$ production that occurred in Dutch canals when sea water was admitted. Sulphate-reducing bacteria tolerating $5 \% \mathrm{NaCl}$ or more are well known: ZoBell \& Rittenberg (1948) mentioned several instances of high salt tolerance in their review of the earlier literature; further examples are strain Canet 41 which multiplied in presence of $0-12 \% \mathrm{NaCl}$ (Senez, 1951), and Iya \& Sreenivasaya's (1945) strain which multiplied in presence of $0-13 \% \mathrm{NaCl}$, most rapid multiplication occurring with $6 \% \mathrm{NaCl}$.

Negative results in growth experiments with sulphate-reducing bacteria can sometimes be attributed to inadequate control of the redox potential of the media, particularly when small inocula are used (Grossman \& Postgate, $1953 a$ ); difficulties of this kind might account for some of the discrepant results reported in the earlier literature. The present paper reports an examination of the salt tolerance of seven strains of sulphate-reducing bacteria (four fresh-water strains and three strains of salt-water origin) in media in which the redox potential was poised with cysteine. In order to judge whether salt tolerance resembled an 'adaptive' or 'mutational' phenomenon, the numbers of organisms of each strain which were viable at different salt concentrations were determined. The nature of the ions concerned in the salt relationships of some of these strains has been studied in greater detail by replacement studies such as have been used with the 'strong' halophiles (review by Flannery, 1956).

\section{METHODS}

Organisms. Seven strains called Desulphovibrio desulphuricans were used: Beckton 1, a fresh-water strain isolated from sewage sludge (National Collection of Industrial Bacteria [NCIB] 8319); Hildenborough (fresh water) from clay (NCIB 8303); Teddington $\mathbf{R}$ (fresh water) from Thames mud (NCIB 8312); Wandle (fresh water) from the River Wandle at Wandsworth (NCIB 8305); British Guiana (of salt-water origin) from 'sling mud' (NCIB 8403); Canet 41 (salt-water origin) from Etang de Canet, Perpignan, France (kindly given by Dr J. Senez; NCIB 8393); El Agheila Z (salt-water origin) from a sulphur-producing lake in Libya (NCIB 8380) (Adams, Butlin, Hollands \& Postgate, 1951). The strains British Guiana, El Agheila Z, Hildenborough and Wandle were originally isolated by the method of Butlin, Adams \& Thomas (1949) using $\mathrm{Na}_{2} \mathrm{SO}_{3} .7 \mathrm{H}_{2} \mathrm{O}(3 \%)$ to hinder the growth of contaminants; Beckton 1, Canet 41 and Teddington $R$ were isolated without this.

Cultivation. Stocks were kept in a freeze-dried condition, but during work on a particular strain it was subcultured weekly in the lactate + yeast extract + sulphate medium $\mathrm{C}$ of Butlin et al. (1949) made up with analytical grade reagents where available. This medium contained no added $\mathrm{NaCl}$, but small amounts of sodium and chloride ions were present $\left(0.014 \%(w / v) \mathrm{Na}^{+}\right.$, $0.065 \%(\mathrm{w} / \mathrm{v}) \mathrm{Cl}^{-}$; all percentages quoted in this paper are $\mathrm{w} / \mathrm{v}$ except where otherwise stated). Cultures (usually $5 \mathrm{ml}$. in $6 \times \frac{5}{8}$ in. test tubes) were incubated at $30^{\circ}$ in McIntosh \& Fildes anaerobic jars containing $\mathrm{H}_{2}+\mathrm{CO}_{2}$ $(1 \%, v / v)$. For experiments requiring large quantities of organisms, medium $\mathrm{C}$ 
was supplemented with tryptone (Oxoid, $0.5 \%$ ) and the yeast extract brought up to $0.4 \%$. Such cultures were grown in 2 l. flasks with a plug containing 1:1 (v/v) pyrogallol (sat.) and $\mathrm{Na}_{2} \mathrm{CO}_{3}$ (sat.) or in $400 \mathrm{ml}$. flasks in anerobic jars; the bacteria were harvested by centrifugation after 4 days of incubation. All media were supplemented with cysteine hydrochloride $(5 \mu \mathrm{mole} / \mathrm{ml}$.) and a trace of ferrous ammonium sulphate $(4 \mu \mathrm{g} . / \mathrm{ml}$.). Media for natural or induced salt-tolerant strains were supplemented with the requisite amounts of $\mathrm{NaCl}$. All media and solutions to be added thereto were sterilized by autoclaving except the cysteine hydrochloride solution which was sterilized by Seitz filtration. The $\mathrm{pH}$ value was finally adjusted to $7 \cdot 4 \pm 0 \cdot 2$ with sterile $\mathrm{N}-\mathrm{NaOH}$.

Counting procedures. Viable counts were carried out by the method of Grossman \& Postgate (1953b). Serial decimal dilutions $(0.5 \mathrm{ml} . \rightarrow 5 \mathrm{ml}$.) of a fully grown culture were made in a mineral solution consisting of medium $\mathbf{C}$ without lactate, yeast extract or sulphate (supplemented with $2.5 \% \mathrm{NaCl}$ for salt-water strains) and $0.5 \mathrm{ml}$. samples of the dilutions were tested in quintuplicate in $4.5 \mathrm{ml}$. portions of medium $\mathrm{C}$ supplemented with the appropriate quantity of $\mathrm{NaCl}$, cysteine hydrochloride and sufficient ferrous ammonium sulphate to indicate growth by blackening (0.05\%). In certain instances $\mathrm{MgCl}_{2}$ or $\mathrm{Na}_{2} \mathrm{SO}_{4}$ replaced some or all of the $\mathrm{NaCl}$ in the test medium. By this procedure the test media contained, when finally inoculated, extra $\mathrm{NaCl}$ equivalent to one-in-ten dilution of the mineral solution in which the culture being tested was diluted. With fresh-water strains this error was ignored; with salt-water strains carry-over amounted to $\mathbf{0 . 2 5} \% \mathrm{NaCl}$, and allowance was made for this in preparing the test media. Because of this carry-over, $0 \cdot 25 \% \mathrm{NaCl}$ was the lowest salt concentration in which salt-water organisms were usually tested. The tubes were incubated until no further blackening was observed. The most probable numbers (M.P.N) of viable bacteria in the original sample were then obtained from statistical tables (Min. of Health, 1939); counts recorded in the figures as $\log$ M.P.N./ml. $=\mathbf{0 . 6}$ represent experiments in which no growth occurred after quintuplicate decimal $(0.5 \mathrm{ml} . \rightarrow 5 \mathrm{ml}$.) dilution of the parent culture directly into the test medium; they thus signify an absolute M.P.N. of less than 2 viable organisms $/ 5 \mathrm{ml}$. culture, the usual volume of the cultures examined during this work. In certain tests with strain British Guiana the procedure was scaled up in an attempt to detect viable salt-tolerant variants of even lower M.P.N./ml.; the decimal dilutions from the parent culture were $5 \mathrm{ml}$. $\rightarrow 50 \mathrm{ml}$. as well as the higher dilutions mentioned already.

Total counts were determined by diluting a culture in the appropriate mineral solution, heating to abolish motility and counting microscopically in a Thoma haemocytometer (Hawksley Ltd., London) of $0.02 \mathrm{~mm}$. depth.

Lysis experiments. Organisms of 'strong' halophiles sometimes burst on transfer to distilled water, owing to entry of water by osmosis (Christian, 1956). Attempts to demonstrate osmotic bursting with certain salt-tolerant strains of Desulphovibrio desulphuricans were made by adding small volumes of a thick suspension of organisms to saline and to distilled water and comparing the turbidities of the suspensions at intervals. The procedure was 
checked by using the halophilic organism NCIB 8668 (kindly given by Professor F. Egami) which showed an immediate decrease in turbidity in distilled water to give a final optical density $16 \%$ the original value in $1 \mathrm{~min}$.

Optical density measurements. These were carried out in the E.E.L. colorimeter (Evans Electroselenium Ltd., Harlow, Essex) calibrated with the Hildenborough strain of Desulphovibrio desulphuricans.

Irradiation with ultraviolet light. Samples from a fully grown culture were irradiated from a $7 \mathrm{~W}$. jacketed 12 in. Hanovia UV lamp (Hanovia Ltd., Slough) emitting maximally at $253 \cdot 7 \mu$. The culture fluid was $2 \mathrm{~mm}$. deep, and treated in a Petri dish $35 \mathrm{~cm}$. from the radiation source.

\section{RESULTS}

\section{Distribution of $\mathrm{NaCl}$-tolerance in 'normal' populations}

The numbers of bacteria viable in media of different $\mathrm{NaCl}$ concentrations were determined using fully grown cultures of the 7 strains of Desulphovibrio desulphuricans. The distribution curves obtained (Figs. 1, 2) can be divided into two main types.

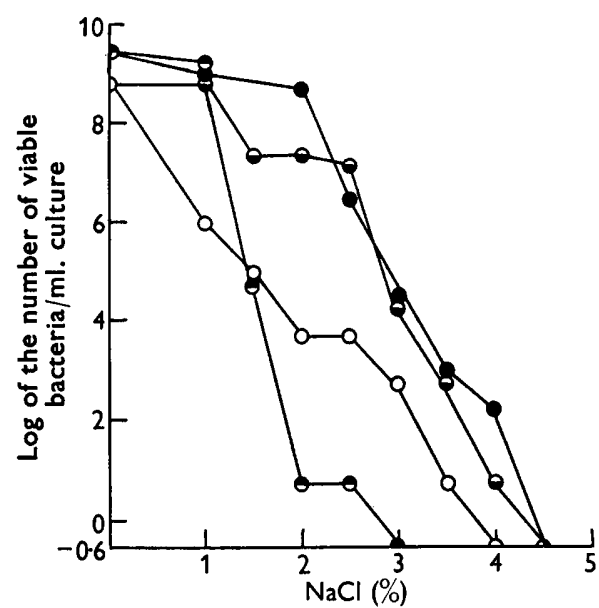

Fig. 1

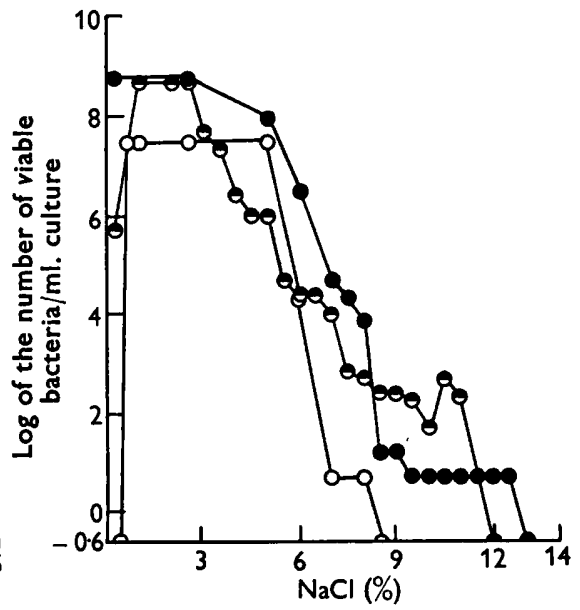

Fig. 2

Fig. 1. Numbers of four fresh-water strains of Desulphovibrio desulphuricans viable in media of various $\mathrm{NaCl}$ concentrations. $\bullet$, Hildenborough; $\ominus$, Wandle; $\ominus$, Teddington R; O, Beckton 1.

Fig. 2. Numbers of three salt water strains of Desulphovibrio desulphuricans viable in media of various $\mathrm{NaCl}$ concentrations. O, British Guiana; $\bullet$, Canet $41 ; \Theta$, El Agheila Z.

\section{Fresh-woter organisms}

Strains Beckton 1, Teddington R, Hildenborough and Wandle, normally grown in medium $\mathrm{C}$ without extra $\mathrm{NaCl}$, showed a relatively small range of salt tolerance; salt-tolerant variants did not appear above $3-4 \% \mathrm{NaCl}$. Strains Hildenborough and Wandle showed a wider range of salt tolerance than the other two strains, possibly because of the procedure used during their isolation (see Discussion). Strain Hildenborough showed atypical growth 
in higher salt concentration (3-4 \% NaCl); the bacteria were associated with the precipitate and blackening did not extend throughout the supernatant medium.

\section{Salt-water organisms}

The three organisms isolated from saline environments were normally grown in medium $\mathrm{C}+2.5 \%$ extra $\mathrm{NaCl}$. They differed markedly from the freshwater types in that variants tolerating high $\mathrm{NaCl}$ concentrations were present in normal populations. These three organisms differed on the basis of the population distributions in subnormal $\mathrm{NaCl}$ concentrations.

Strain British Guiana. This strain showed true halophily in the sense that none of the bacteria was viable with a low $(0.4 \%) \mathrm{NaCl}$ concentration. When a large innoculum was used $(0.5 \mathrm{ml}$. or $5 \mathrm{ml}$. parent culture) a black precipitate of ferrous sulphide often developed in the subculture, but when this was examined microscopically no bacteria could be seen adhering to the particles, and none was removed by washing the precipitate. A maximum viable count was obtained in $0.6 \% \mathrm{NaCl}$, but in $0.5 \% \mathrm{NaCl}$ the results varied considerably from experiment to experiment and were irregular in that tubes from higher dilutions sometimes gave blackening when tubes from lower dilutions did not.

Strain Canet 41. The whole population of this strain was viable in $0.25 \%$ $\mathrm{NaCl}$. This strain showed the widest range of salt tolerance, confirming and extending the original observation of Senez that cultures of Canet 41 grew with 0-12\% NaCl (Senez, 1951).

Strain El Agheila Z. This strain showed an intermediate behaviour in which most of the organisms were not viable with $0.25 \% \mathrm{NaCl}$, but some nonexacting variants were present; the proportion of the latter was higher in young cultures (Table 1) than in older ones.

Table 1. Effect of age of parent culture on the viability of Desulphovibrio desulphuricans strain El Agheila $\mathbf{Z}$ in media of low salt concentration

The viable populations in cultures of different ages were counted in media containing: (a) $1 \% \mathrm{NaCl}$ (in which a maximum viable count was obtained); (b) $0.25 \% \mathrm{NaCl} ;(c) 0.25 \%$ $\mathrm{NaCl}+\mathrm{MgCl}_{2}$ to $\mathrm{Cl}^{\prime}$ concentration equivalent to $(a)$. The figures quoted are numbers of viable bacteria/ml. original culture.

Age of parent

culture

(days)

3

6

7

$1 \% \mathrm{NaCl}$
$\left(0 \cdot 6 \% \mathrm{Cl}^{\prime}\right)$
$5 \times 10^{8}$
$5 \times 10^{8}$
$5 \times 10^{8}$

$$
\begin{gathered}
0.25 \% \mathrm{NaCl} \\
3.4 \times 10^{6} \\
5 \times 10^{5} \\
1.4 \times 10^{4}
\end{gathered}
$$

$0.25 \% \mathrm{NaCl}$
$+0 \cdot 61 \% \mathrm{MgCl}_{2}$
(total $\left[\mathrm{Cl}^{\prime}\right]=0.6 \%$ )
$1 \times 10^{8}$
$7 \times 10^{7}$
$5 \times 10^{6}$

\section{Distribution of $\mathrm{NaCl}$ tolerance in 'trained' populations}

Strain Wandle was 'trained' to tolerate $\mathrm{NaCl}$ by subculturing eleven times in medium $\mathrm{C}$ containing $4 \% \mathrm{NaCl}$. The distribution of salt-tolerant variants in a population grown in this medium was then comparable with that of Canet 41, the most salt-tolerant organism examined (Fig. 3).

Strain Canet 41 was trained to high salt resistance by twelve subcultures in medium $\mathrm{C}$ containing $10 \% \mathrm{NaCl}$. The whole population of such a culture was 
then viable in $\mathrm{NaCl}$ concentrations ranging from 1 to $10 \%$ and variants tolerating up to $16 \% \mathrm{NaCl}$ were present (Fig. 4).

Three separate attempts to train strain British Guiana to grow with $0 \cdot 4 \% \mathrm{NaCl}$ were not successful. Cultures able to grow with $0.5 \%$ or $0.45 \% \mathrm{NaCl}$ were obtained without much difficulty, but even after several subcultures at these salt concentrations the trained cultures would not grow with $\mathbf{0 . 4} \%$ or less $\mathrm{NaCl}$. The substrain trained to grow with $0.45 \% \mathrm{NaCl}$ was irradiated with u.v.-radiation for $\mathbf{4 0}$ sec., which gave about $1 \%$ survival of the parent strain, but no variants able to grow with $\mathbf{0 \cdot 3} \%$ or less $\mathrm{NaCl}$ were obtained.

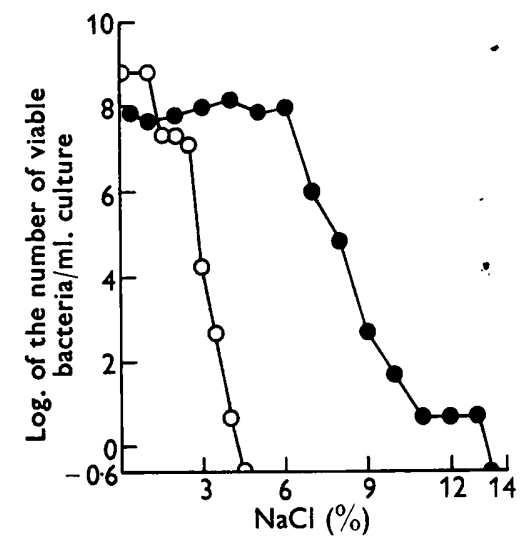

Fig. 3

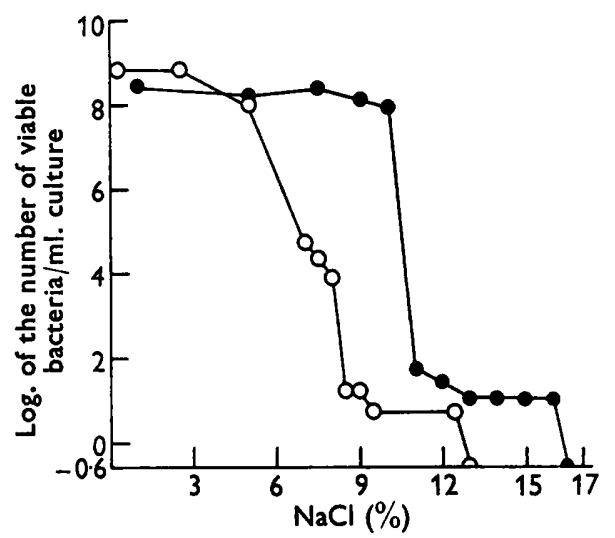

Fig. 4

Fig. 3. Numbers of Desulphovibrio desulphuricans strain Wandle and of a sub-strain trained to $4 \% \mathrm{NaCl}$ viable in media of various $\mathrm{NaCl}$ concentrations. $O$, normal strain; , adapted strain.

Fig. 4. Numbers of Desulphovibrio desulphuricans strain Canet 41 and of a sub-strain trained to $10 \% \mathrm{NaCl}$ viable in media of various $\mathrm{NaCl}$ concentrations. $O$, normal strain; , adapted strain.

During training the cultures were morphologically unusual and multiplication tended to be restricted to the precipitate in the medium. Few typical vibros were visible under the microscope and many sluggishly motile fat spirilloid organisms, some $50 \mu$. long, were seen. Morphologically aberrant forms in unfamiliar salt concentration have been reported with sulphatereducing bacteria (Baars, 1930; Rittenberg, 1941) as with other bacteria (Flannery, 1956). The substrain acclimatized to $0 \cdot 45 \% \mathrm{NaCl}$ became morphologically more normal, however, after five or more subcultures in this salt concentration and typical vibrios then appeared throughout the medium, though a few spirilloid forms persisted.

\section{Ions responsible for the effects of $\mathrm{NaCl}$ on growth}

Flannery, Doetsch \& Hansen (1952) showed by replacement experiments with other salts that the 'strong' halophile Vibrio costicolus required sodium rather than chloride ion for multiplication; Robinson \& Gibbons (1952) observed that Micrococcus denitrificans required sodium chloride specifically 
for multiplication. Replacement experiments were used to study the nature of the effects of $\mathrm{NaCl}$ on the growth of various strains of Desulphovibrio desulphuricans.

Strain Wandle. This strain was tested in media in which $\mathrm{Na}_{2} \mathrm{SO}_{4}$ or $\mathrm{MgCl}_{2}$ replaced $\mathrm{NaCl}$ (Fig. 5). The distribution of salt-tolerant variants in $\mathrm{Na}_{2} \mathrm{SO}_{4}$ was similar to that in $\mathrm{NaCl}$ provided the concentrations were expressed in $\% \mathrm{Na}^{+}$; the organisms tolerated a much higher concentration of $\mathrm{Cl}^{\prime}$ when the cation was $\mathrm{Mg}^{++}$. Hence, subject to certain provisos about the dissociation of these salts (see Discussion), the inhibitory effect of $\mathrm{NaCl}$ is attributable to the sodium ion; it is neither a non-specific osmotic effect nor due to chloride ion.

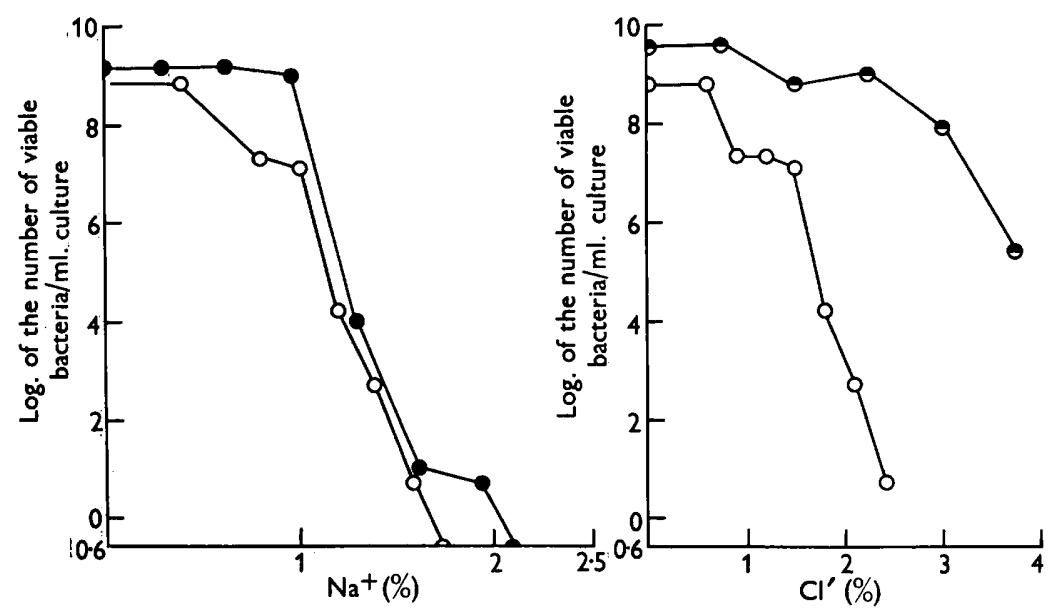

Fig. 5. Numbers of Desulphovibrio desulphuricans strain Wandle viable in media containing various concentrations of $\mathrm{NaCl}, \mathrm{Na}_{2} \mathrm{SO}_{4}$ or $\mathrm{MgCl}_{2}$. $\bigcirc, \mathrm{NaCl} ; \ominus, \mathrm{Na}_{2} \mathrm{SO}_{4} ; \ominus, \mathrm{MgCl}_{2}$.

Strain $\mathrm{El}$ Agheila $\mathrm{Z}$. The requirement of the majority of organisms in a 'normal' population of strain El Agheila $\mathrm{Z}$ was shown by a similar procedure to be for sodium rather than for chloride ion (Table 1 ). $\mathrm{Na}_{2} \mathrm{SO}_{4}$, added to the medium so that the final concentration of $\mathrm{Na}^{+}$was equivalent to $1 \% \mathrm{NaCl}$, permitted the whole population to multiply; $\mathrm{MgCl}_{2}$, added to give an equivalent $\mathrm{Cl}^{\prime}$ concentration, did not do this. $\mathrm{MgCl}_{2}$ had a partial synergistic effect with $\mathrm{NaCl}$ (Table 1) which was most pronounced with young cultures; it was not studied further.

The inhibitory effect of high concentrations of $\mathrm{NaCl}$ on strain $\mathrm{El}$ Agheila $\mathrm{Z}$ could not be attributed solely to sodium ion. A 'normal' culture contained about 26 organisms $/ \mathrm{ml}$. which were viable in $9 \% \mathrm{NaCl}$, but when media were made up with $1 \% \mathrm{NaCl}+\mathrm{Na}_{2} \mathrm{SO}_{4}$ together equivalent in $\mathrm{Na}^{+}$to $9 \% \mathrm{NaCl}$, or with $1 \% \mathrm{NaCl}+\mathrm{MgCl}_{2}$ together equivalent in $\mathrm{Cl}^{\prime}$ to $9 \% \mathrm{NaCl}$, no viable bacteria were detected.

Strain British Guiana. The requirement of this strain for $\mathrm{NaCl}$ was examined in a similar manner to that used with strain El Agheila Z. A maximum 
viable count was obtained with $1 \% \mathrm{NaCl}$ or with $\mathrm{MgCl}_{2}$ added to the medium so that the final $\mathrm{Cl}^{\prime}$ concentration was equivalent to $1 \% \mathrm{NaCl}$. With $\mathrm{Na}_{2} \mathrm{SO}_{4}$ added to give a final $\mathrm{Na}^{+}$concentration equivalent to $1 \% \mathrm{NaCl}$, however, a maximum count was not obtained; the results of tests with $\mathrm{Na}_{2} \mathrm{SO}_{4}$ were very irregular and recalled the dilution counts in $0.5 \% \mathrm{NaCl}$ referred to earlier. Hence, in contrast to strain El Agheila Z, strain British Guiana required chloride ion rather than sodium ion for multiplication.

The inhibition of strain British Guiana by high salt concentrations could not be attributed solely either to $\mathrm{Na}^{+}$or $\mathrm{Cl}^{\prime} ; \mathbf{2 \cdot 2} \times 10^{4}$ organisms $/ \mathrm{ml}$. were viable with $6 \% \mathrm{NaCl}$ but only $7 \times 10^{2} / \mathrm{ml}$. grew in a medium containing $1 \%$ $\mathrm{NaCl}+\mathrm{Na}_{2} \mathrm{SO}_{4}$ together equivalent in $\mathrm{Na}^{+}$to $6 \% \mathrm{NaCl}$, and only $5 \times 10^{2} / \mathrm{ml}$. grew in a medium containing $1 \% \mathrm{NaCl}+\mathrm{MgCl}_{2}$ together equivalent in $\mathrm{Cl}^{\prime}$ to $6 \% \mathrm{NaCl}$. As with strain El Agheila Z, the mixed salts were more inhibitory than $\mathrm{NaCl}$ alone.

Attempts to observe osmotic lysis. No lysis was detected turbidimetrically when strain British Guiana, strain Wandle trained to multiply in $4 \% \mathrm{NaCl}$ or strain Canet 41 trained to multiply in $10 \% \mathrm{NaCl}$ were exposed to distilled water (0.27-0.42 mg. dry wt. bacteria $/ \mathrm{ml}$.) for $2 \frac{1}{2}-3 \mathrm{hr}$. at room temperature.

Ratio of viable to total count. The procedure used in this work for estimating viable bacteria was that of Grossman \& Postgate (1953b). These authors obtained viable counts amounting to between 20 and $70 \%$ of the total count, the error being mainly attributable to losses during manipulation. The percentage recoveries of viable bacteria obtained in the present work were of similar orders (Table 2) with the exception of strain British Guiana, suggesting that high manipulative losses occurred with this strain.

Table 2. Relationship between viable counts and total counts of seven strains of Desulphovibrio desulphuricans

\begin{tabular}{|c|c|c|c|}
\hline Strain & $\begin{array}{c}\text { Viable organisms } \\
\text { in original culture } \\
(\mathrm{no} / \mathrm{ml} .)\end{array}$ & $\begin{array}{l}\text { Total number of } \\
\text { organisms visible in } \\
\text { haemocytometer } \\
\text { (no./ml.) }\end{array}$ & $\begin{array}{c}\text { Viability } \\
\text { (\% total count) }\end{array}$ \\
\hline Beckton 1 & $1.0 \times 10^{\theta}$ & $1.4 \times 10^{9}$ & $71 \cdot 4$ \\
\hline Hildenborough & $1.0 \times 10^{9}$ & $1.4 \times 10^{9}$ & $71 \cdot 4$ \\
\hline Teddington $\mathbf{R}$ & $1.0 \times 10^{9}$ & $1.6 \times 10^{9}$ & $62 \cdot 5$ \\
\hline Wandle & $7 \cdot 0 \times 10^{8}$ & $1 \cdot 14 \times 10^{9}$ & $61 \cdot 4$ \\
\hline British Guiana & $3.4 \times 10^{7}$ & $4.4 \times 10^{8}$ & $7 \cdot 7$ \\
\hline Canet 41 & $7 \cdot 0 \times 10^{8}$ & $1.3 \times 10^{9}$ & $53 \cdot 8$ \\
\hline El Agheila Z & $2.6 \times 10^{8}$ & $9 \cdot 25 \times 10^{8}$ & $28 \cdot 1$ \\
\hline
\end{tabular}

\section{DISCUSSION}

Nature of the effect of $\mathrm{NaCl}$ on growth. The experiments in which $\mathrm{NaCl}$ was replaced by $\mathrm{Na}_{2} \mathrm{SO}_{4}$ or $\mathrm{MgCl}_{2}$ indicated that the requirement of strain El Agheila $\mathrm{Z}$ was primarily for sodium ion, and that this ion was also primarily responsible for the inhibitory effects of $\mathrm{NaCl}$ on the viability of strain Wandle. These strains thus resemble Vibro costicolus (Flannery, 1952) in that sodium ion is of primary importance in their growth. On the other hand, the require- 
ment of strain British Guiana was primarily for chloride ion and not sodium ion; thus it resembled neither $V$. costicolus nor Micrococcus denitrificans (Robinson \& Gibbons, 1952).

The significance of replacement experiments on inhibition of multiplication by strong $\mathrm{NaCl}$ solutions can be criticized on the grounds that, if $\mathrm{MgCl}_{2}$ were imperfectly dissociated like $\mathrm{CdCl}_{2}$ (strong solutions of which contain much of the ionic species $\mathrm{CdCl}^{+}$and hence have a chloride ion concentration lower than theoretical), then the actual chloride ion concentration in the tests reported here might be much lower than the total added chloride would indicate. This possibility was examined by plotting the curves relating the equivalent conductivity to the concentration of $\mathrm{NaCl}$ and $\mathrm{MgCl}_{2}$ derived from International Critical Tables and interpolating the values giving comparable recoveries of viable organisms of strain Wandle. Even if the whole of the deviation from theoretical of $\mathrm{MgCl}_{2}$ were attributed to an association of the type $\mathrm{Mg}^{++}+\mathrm{Cl}^{\prime} \rightarrow \mathrm{MgCl}^{+}$, the chloride ion concentration would still have been $c .35 \%$ greater than in the equivalent $\mathrm{NaCl}$ solution. The effect of sodium ion on the growth of strains Wandle and El Agheila $\mathrm{Z}$ emphasizes the fact, mentioned by Butlin et al. (1949), that $3 \% \mathrm{Na}_{2} \mathrm{SO}_{3} \cdot 7 \mathrm{H}_{2} \mathrm{O}$ should not be used to suppress contaminants if obligate non-halophilic strains of Desulphovibrio desulphuricans are being isolated, because a $3 \%$ solution of $\mathrm{Na}_{2} \mathrm{SO}_{3} \cdot 7 \mathrm{H}_{2} \mathrm{O}$ has a $\mathrm{Na}^{+}$concentration equivalent to $1 \cdot 4 \% \mathrm{NaCl}$. Strains Hildenborough and Wandle were isolated by this procedure and this may account for their higher salt tolerance compared with strains Teddington $\mathbf{R}$ and Beckton 1; strain El Agheila $\mathrm{Z}$ was also treated with $3 \% \mathrm{Na}_{2} \mathrm{SO}_{3} \cdot \mathbf{7} \mathrm{H}_{2} \mathrm{O}$ (thus passing through a medium of $\mathrm{Na}^{+}$concentration equivalent to $3.9 \% \mathrm{NaCl}$ ) which may have accentuated its tendency to halophily. All media used in the present work, even when not supplemented with $\mathrm{NaCl}$, contained low concentrations of $\mathrm{Na}^{+}$and $\mathrm{Cl}^{\prime}$; for this reason experiments similar to those of Ware, Childs \& Smith (1955) on faecal organisms, to determine the effects of very low concentrations of $\mathrm{NaCl}$ on growth, were not carried out.

Most of the strains examined in this work, whether of salt- or fresh-water origin, gave maximum viabilities in $1 \% \mathrm{NaCl}$, supporting Miller's (1949) contention that $1 \% \mathrm{NaCl}$ is most satisfactory for growth of both types of sulphate-reducing bacteria. However, strain Beckton 1 was an exception and only a small proportion of the population was viable in $1 \% \mathrm{NaCl}$. In spite of Gahl \& Anderson's (1928) demonstration of salt-sensitive strains in oil-well waters, media supplemented with $1 \% \mathrm{NaCl}$ have been recommended as 'general purpose' media for the growth of sulphate-reducing bacteria. The existence of very salt-sensitive strains such as strain Beckton 1 confirms that such media should be used cautiously.

Halophily and nomenclature in Desulphovibrio. The distribution patterns of salt tolerance in the strains studied here ranged from the strict $\mathrm{NaCl}$ requirements of strain British Guiana, through the partial $\mathrm{NaCl}$ requirement of strain El Agheila $Z$ and the wide salt tolerance of strain Canet 41, to the comparative salt-sensitivity of the fresh-water strains. Thus there seems to be little difference of kind between the salt-water and fresh-water types: they 
differ mainly in the number of variants produced which are able to tolerate particularly high or low salt concentrations. Whether these variants should properly be called mutants depends more on one's definition of the term mutant than on the experimental data presented here, for there is no obvious qualitative difference between the few variants of strain Canet 41 which are able to grow in $10 \% \mathrm{NaCl}\left(c .1\right.$ organism in $\left.10^{8}\right)$, which one would normally call mutants and the many able to grow with $6 \% \mathrm{NaCl}(c .1$ organism in 100) which are far more plentiful than classical mutants. The procedure used in this work would not have detected variants if their proportion was below c. 1 in $10^{9}$ ordinary organisms, and it may well be that strain British Guiana is an extreme form of the El Agheila $\mathbf{Z}$ type, capable in principle of producing non-exacting variants, but at so low a frequency that the methods used here did not detect them. These strains differed in the character of their sodium chloride requirements, one requiring primarily sodium ion and the other requiring primarily chloride ion, and it is not unreasonable that the frequency with which 'chloride-less' variants arise should differ from the frequency with which 'sodium-less' variants occur.

For similar reasons the question which of these strains should properly be termed 'halophilic' has, like the mutant question, a semantic flavour. None of them, not even strain Canet 41 after training to multiply in $10 \% \mathrm{NaCl}$, showed the osmotic lysis in distilled water characteristic of the more exacting halophiles of other genera studied by Christian (1956). Yet because it required some $\mathrm{NaCl}$ for growth, strain British Guiana might reasonably be called a halophile, but strain Canet 41 should then be termed a facultative halophile in spite of its marine origin. Strain El Agheila $\mathbf{Z}$ is intermediate in behaviour but is still a facultative halophile since a proportion of the population grew without added $\mathrm{NaCl}$.

ZoBell, in Bergey's Manual (1948), decided to retain the specific name aestuarii for salt-requiring members of the genus Desulphovibrio because of Rittenberg's exception to Baars's report that marine strains could be trained to grow without $\mathrm{NaCl}$. In the present work strains Canet 41 and $\mathrm{El} \mathrm{Agheila} \mathrm{Z}$ conformed to Baars's observations, but we were unable to 'train' strain British Guiana to grow without extra $\mathrm{NaCl}$; the behaviour of this strain is thus comparable with the two studied by Rittenberg (1941) and reported by ZoBell \& Rittenberg (1948). The apparent divergence between the results of Rittenberg and those of Baars can be reconciled if Rittenberg be regarded as having selected accidentally two strains of British Guiana type. Baars regularly added $\mathrm{H}_{2} \mathrm{~S}$ water to his cultures at inoculation, but Rittenberg's media did not include a chemical reducing agent, and it is therefore possible that, even had his strains been of the El Agheila $\mathrm{Z}$ type (c. $0 \cdot 1 \%$ of the population viable without extra $\mathrm{NaCl}$ ) he would have failed to 'train' them. In our laboratory, strain El Agheila $\mathrm{Z}$ was believed to be an exacting halophile until the present work was undertaken; it now seems clear that the failure of this strain to grow in unsupplemented media, a failure which contrasted with the behaviour of strain Canet 41, was because the customary 1/100 inoculum was effectively $1 / 10^{5}$ in terms of organisms viable without added salt. An 
inoculum of $1 / 10^{5}$ is unlikely to grow without added reducing agent (Grossman \& Postgate, 1953a).

The present work has shown a complete gradation of behaviour towards $\mathrm{NaCl}$ within the genus Desulphovibrio, ranging from very salt-sensitive types to salt-requiring types; at no point in this gradation is the difference from the neighbouring type large. The question arises whether the use of the specific name aestuarii for salt-requiring strains is justified at all. Certainly the name cannot be applied automatically to strains of marine origin since these may be of the Canet 41 or El Agheila Z types, which are clearly facultatively halophilic strains of $\boldsymbol{D}$. desulphuricans, resembling the acclimatized sub-strain of Wandle. It could be argued that the name $D$. aestuarii might be retained, but be restricted to salt-water strains of the British Guiana type. The present authors incline to the opinion that the differences so far established between this strain and the others, i.e. requirement for $\mathrm{Cl}^{\prime}$ rather than $\mathrm{Na}^{+}$, and low rate of production of non-exacting variants, are hardly sufficient to justify separate species status unless supported by further morphological and biochemical differences. These are not yet apparent.

We are indebted to Dr M. Ingram and Dr J. H. B. Christian for valuable discussions and to our colleagues in the Microbiology Group for advice and encouragement. This paper is published by permission of the Director, Chemical Research Laboratory.

\section{REFERENCES}

Adams, M. E., Butlin, K. R., Hollands, S. J. \& Postgate, J. R. (1951). The role of hydrogenase in the autotrophy of Desulphovibrio. Research, Lond. 4, 245.

BAARS, J. K. (1930). Over sulfaatreductie door bacterien. Dissertation, Meinema, Delft.

Bergey's Manual of Determinative Bacteriology. Ed. by Breed, R. S., Murray, E. G. D. \& Hitchens, A. P. (1948). Baltimore: The Williams \& Wilkins Co.

Butlin, K. R., Adams, M. E. \& Thomas, M. (1949). The isolation and cultivation of sulphate-reducing bacteria. J. gen. Microbiol. 3, 46.

Christian, J. H. B. (1956). Lysis on dilution of bacteria grown in high salt concentrations. J. gen. Microbiol. 15, vi.

Delden, A. van (1903). Beitrag zur Kenntnis der Sulfatreduktion durch Bakterien. Zbl. Bakt. (2. Abt.), 11, 113.

Flannery, W. L. (1956). Current status of knowledge of halophilic bacteria. Bact. Rev. 20, 49.

Flannery, W. L., Doetsch, R. N. \& Hansen, P. A. (1952). Salt desideratum of Vibrio costicolus, an obligate halophilic bacterium. 1. Ionic replacement of sodium chloride requirement. J. Bact. 64, 713.

Gahl, R. \& Anderson, B. (1928). Sulphate reducing bacteria in California oil waters. Zbl. Bakt. (2. Abt.), 73, 331.

Grossman, J. P. \& Postgate, J. R. (1953a). Cultivation of sulphate-reducing bacteria. Nature, Lond. 171, 600.

Grossman, J. P. \& Postgate, J. R. (1953b). The estimation of sulphate-reducing bacteria (D. desulphuricans). Proc. Soc. appl. Bact. 16, 1.

Iya, K. K. \& Sreenivasaya, M. (1945). Studies in the sulphur formation at Kona, Masulipatam-II. Curr. Sci. 14, 267.

Kluyver, A. J. \& BaArs, J. K. (1932). On some physiological artefacts. Proc. Acad. Sci. Amst. 35, 370. 
Miller, L. P. (1949). Rapid formation of high concentrations of hydrogen sulphide by sulfate-reducing bacteria. Contr. Boyce Thompson Inst. 15, 437.

Ministry of Health (1939). The bacteriological examination of water supplies. Rep. publ. Hlth med. Subj.. Lond., no. 71, 2nd ed. London: H.M.S.O.

Rittenberg, S. C. (1941). Studies on marine sulfate-reducing bacteria. Dissertation no. 650, Univ. Calif., La Jolla.

Robinson, J. \& Gibbons, N. E. (1952). The effect of salts on the growth of Micrococcus halodenitrificans (n.sp). Canad. J. Bot. 30, 147.

Senez, J. (1951). Étude comparative de la croissance de Sporovibrio desulfuricans sur pyruvate et sur lactate de soude. Ann. Inst. Pasteur, 80, 395.

WARe, G. C., Childs, E. \& Smith, H. M. (1955). The effect of salt concentration on the growth of bacteria in dilute nutrient solutions. J. appl. Bact. 18, 446.

ZoBell, C. E. \& Rittenberg, S. C. (1948). Sulfate-reducing bacteria in marine sediments. J. mar. Res. 7, 602.

(Received 12 March 1957) 